\title{
The Effect of Procyclical on Income Smoothing with Financial Leverage as Moderation Variables in Banking Companies
}

\author{
Aprilya Dwi Yandari", Erina Sudaryati \\ Department of Accounting, Airlangga University, Surabaya, Indonesia
}

*Corresponding Author: Aprilya Dwi Yandari, Department of Accounting, Airlangga University, Surabaya, Indonesia

\begin{abstract}
The economic crisis in 2008 gave effect to the governance system in protecting the form of economic stability. Accounting problems that occur when investors take a policy based on expectations and then the price of housing in the next year will be increase. The conditions can make people speculate so that the level of price increases will be high which eventually turned into a bubble property phenomenon. Whereas in macro prudential policy, making a decision based on expectations on the previous price can be explained related to the procyclical. Indication of company in doing income smoothing in order to avoid breach of agreement a debt for company ability to pay its debts. So that, the companies have a high leverage will expected to do income smoothing deviation because the company threatened default. Based on the purpose of the research, the type of research used is explanatory. The population are all conventional bank companies as many as 81 companies with a sample of 29 companies. Analytical technique used logistic regression analysis. The results of the research show that the procyclical action will have a considerable influence in the asymmetry of income smoothing information. In addition, procyclical and financial leverage that as moderation has a considerable influence in the conduct of fraud income smoothing in line with research conducted by Alexandri and Anjani (2014).
\end{abstract}

Keywords: Procyclical, Financial Leverage, Income Smoothing

\section{INTRODUCTION}

The economic crisis in the period of 2008 had an influence on the governance system in protecting the form of economic stability. In addition, it is not in protecting price stability, but still protecting the level of stability of the State financial system. At the end of 2008, a crisis was mounting which coincided with the bankruptcy of the largest investment bank, Lehman Brothers (Nugroho, 2010). The form of accounting problems that occur is when investors take a policy based on an expectation, the housing price in the following year will increase. Such conditions will later make the community speculate so that the level of price increase will be higher which eventually turns into a bubble property phenomenon. This can explain the bubble phenomenon that occurred in America several years ago. Therefore, back to macroprudential policy where a decision is made based on an expectation at the previous price that can explain related to procyclical. Therefore, from this explanation when viewed in the conditions that occur in Indonesia, the policy that occurs when the fiscal policy pattern tends to be procyclical rather than countercyclical. The existence of an economic crisis in many countries will provide encouragement for each country.

In procyclical banking companies occur when companies are in the form of provisioning, which will undergo procyclical when in a state of low economic expansion and a high crisis. The low level of provision at the time of expansion is due to the poor quality of credit, and vice versa. When the establishment of a high provision during a crisis was caused by an increase in poor credit quality. So that the procyclical pattern in the formation will eventually burden the bank when the crisis occurs. This happens because the bank must form a higher provision by using its profit. So that banking companies will carry out an effort to deviate income smoothing in improving the company's profit position.

When a banking company experiences an increase in credit value, the company will attempt to obtain additional funding value for the incident. This will make the company to have a high debt to be able to fulfill it. In addition, the company has a goal to be able to maximize the welfare of shareholders, 
this is in line with the theory of pecking order theory. From the explanation of the information asymmetry that underlies the pecking order theory, the research also uses the ratio variable financial leverage as a moderating variable. This is to see whether the procyclical pattern and financial leverage will have an impact on the occurrence of an income smoothing. Narsa et al (2003) explained that the value of high leverage can result in the lack of investor interest in investing, so that it will encourage income smoothing. This event can make companies tend to make income smoothing. There is an indication of the company in carrying out income smoothing in order to avoid any breach of a debt agreement which is seen based on the company's ability to pay debts using its assets. So companies that have high leverage will be suspected of deviating income smoothing because the company is threatened with default. So that when profits increase or stabilize, the risk of the company will be smaller. This is what can reduce the risk of the company by making the income smoothing. This is the same as the research by Alexandri (2014) which explains that financial leverage has a positive influence on income smoothing. However, this research is contrary to research conducted by Suwito and Herawati (2005) which explains that financial leverage has a negative effect on income smoothing practices.

Therefore, this study was conducted in the banking sector during the 2012-2016 observation period listed on the Indonesia Stock Exchange. This was done because in 2013 Bank Indonesia had completed all the steps needed to transfer banking supervision to OJK. Regarding this, Bank Indonesia has made a statement that the banking industry was in a very good condition. At that time, credit growth conditions experienced worries above $25 \%$. The ratio of non-performing loans is at a low of $1 \%$, the capital adequacy ratio is at $18 \%$, and the ROA ratio is in 3\%. Therefore, the existence of this research is able to provide involvement for users (users) or other researchers related to procyclical.

\section{LITERATURE REVIEW}

\subsection{Business Cycle Theory}

The business cycle is a form of jealousy that always rises and falls when in a position of expansion (recovery) and contraction (recession) in the state of the economy that is at the position of the path from the level of growth (Kiyotaki, 2011). Here are four stages of the economic cycle, namely:

- Expansion is a state of recovery, that is when economic growth can begin to move up with a marked increase in national products, increased employment opportunities, increased work wages and increased corporate profits.

- Peak is the highest part of the desired economic situation after the emergence of expansion when the nominal work and employment opportunities are in a good condition for the State.

- Recession can occur when in an economic condition whose income level is decreasing so that someone will be able to pay taxes will be reduced (Kiyotaki, 2011).

- Trought is a form of declining economic activity that does not continue continuously but stops at the lowest point (trought).

\subsection{Pecking Order Theory}

Nuswandari (2013) provides an explanation related to pecking order theory by assuming that companies have a purpose in maximizing the welfare of shareholders. Pecking order theory was also stated first by Donaldson in 1961 while the naming of pecking order theory was carried out by Myers (1984) in the study of Prabansari and Kusuma (2005). This theory provides an explanation that companies will increasingly support internal financing, namely a funding process that comes from the company's operating output (retained earnings). whereas when needed for external funding processes, the company will issue securities that begin with bonds, then proceed with option-characterized securities or when it has not been achieved by issuing new shares for the most appropriate and safe choice. Other factors are also influenced by information asietri and share issuance costs that can trigger pecking orders (Myers, 1984; Baskin, 1989 in Prince, 2010).

Therefore, pecking order theory can be the basis of information asymmetry, in which managers have more information and better initial information. So that the current market can learn the behavior of managers where pecking order theory can provide a basic reason why companies that have high profits can have quite a bit of debt. The following is because companies can achieve the target of a 
small debt ratio with factors caused that the company does not want funds from external parties (Brealey and Myer, 1995 in Steven and Lina, 2011).

\subsection{Agency Theory}

In a study conducted by Rahmah and Sembiring (2014), explained that Jensen and Meckling (1976) explained that there was an interaction between agencies between one or more principal parties in carrying out other actions by giving results in the past by way of escorting the policy in following up decisions on agent. Scott (2012) also explained that companies can have a contract, where the investor works contracts with managers, as well as agents and principals who have a purpose to increase the existing information utilities.

\subsection{Income Smoothing}

Income smoothing is a management action in increasing market returns (e. Michelson, 2000; S. E. Michelson, Jordan-Wagner, \& Wootton, 2000). The action is carried out so as to have the desired profit value in a company's income statement so that later it can attract the interest of the investment market. When the desired profit is in a stable position, it is able to give confidence to the owner of the company (SE Michelson et al., 2000) which is assisted by directives to give satisfaction to shareholders by means of growth rate and informed earnings stability in the position of accounting rules used (Breton \& Stolowy, 2000). S. E. Michelson et al. (2000) provide an explanation related to income smoothing carried out by management that focuses on the things used by management in financial information engineering engineering. So there is a contributing factor to the income smoothing with differences in the economic consequence factors of accounting options and profit factors based on self-figures in supporting these income smoothing actions. Therefore, there is previous empirical scientific writing that tests these factors. The empirical results can only explain the results that do not agree because the factors that have not been concluded whether or not have an effect on income smoothing.

\section{RESEARCH METHODS}

Based on the purpose of the study, the type of research used was explanatory. The population is all conventional bank companies as many as 81 companies with a sample of 29 companies. The analysis technique used is logistic regression analysis. In testing this hypothesis the mathematical equation model is used as follows:

Model 1: Procyclical Influence on Income Smoothing

$$
\operatorname{Ln} \frac{\text { ISit }}{1-\text { ISit }}=(\boldsymbol{\beta 0}+\boldsymbol{\beta 1 P C i t})
$$

In testing the hypothesis of this study using a systematic equation model as follows:

Model 2: Procyclical Influences and Financial Leverage on Income Smoothing

$$
\operatorname{Ln} \frac{\text { ISit }}{1-\text { ISit }}=(\beta 0+\beta 1 \text { PCit }+\beta 2 \text { LEVit })
$$

Model 3: Moderated Regression

$$
\begin{array}{r}
\operatorname{Ln} \frac{\text { ISit }}{1-\text { ISit }}=(\beta 0+\beta 1 P C i t+\beta 2 \text { LEVit }+\beta 3 \text { PCit } * \text { LEVit }) \\
\mathbf{I S}_{\text {it }}=\alpha+\beta_{1} \mathbf{P C i t}+\beta_{2} \mathbf{L E V}_{\text {it }}+\beta_{3} \mathbf{P C}_{\mathrm{it}} * \mathbf{L E V}_{\mathrm{it}}+\varepsilon_{\mathrm{it}}
\end{array}
$$

\section{DISCUSSION}

\subsection{Testing the Hypothesis of the Procyclical Effect on Income Smoothing}

In the table below gives the results of logistic regression test obtained from the regression coefficient as follows:

Table1. Results of Hypothesis Testing 1

\begin{tabular}{|l|l|c|c|c|l|l|c|}
\hline \multicolumn{9}{|c|}{ Variables in the Equation } \\
\hline \multicolumn{2}{|c|}{} & B & S.E. & Wald & df & Sig. & $\operatorname{Exp}(\mathbf{B})$ \\
\hline Step & PROCYCLICAL & 3.471 & .470 & 54.567 & 1 & .000 & 32.154 \\
\hline
\end{tabular}


The Effect of Procyclical on Income Smoothing with Financial Leverage as Moderation Variables in Banking Companies

\begin{tabular}{|c|c|c|c|c|c|c|c|}
\hline $1^{\mathrm{a}}$ & Constant & -1.992 & .355 & 31.441 & 1 & .000 & .136 \\
\hline
\end{tabular}

The table above shows the test results on procyclical variables with a regression coefficient of 3.471 and a significance value of 0.000 . The value of the significance level shows a value smaller than 0.05 $(p \leq 0.05)$. This shows that the first hypothesis is accepted, so the procyclical variable affects income smoothing. The results of the research that have been conducted show that procyclical actions will have a considerable influence in carrying out an asymmetry of income smoothing information. As previously explained, when a company, especially in banking, experiences difficulties or a crisis in its financial actions, the managers of the company will commit a fraud to optimize the trust of shareholders to survive in investing in the banking company. The results of this study are consistent with the research conducted by Carvallo et al. (2015) which explains that capital buffers will probably fluctuate over the procyclical state. This is because adjustments will be lower and the regulations for a capital are less significant. So that when there is an act of information asymmetry it might trigger the emergence of procyclicals that can make income smoothing deviant actions.

\subsection{Testing the Procyclical Influence Hypothesis on Income Smoothing as a Moderation Financial Leverage Variable}

In the table below shows the results of logistic regression testing obtained from the regression coefficient as follows:

Table2. Results of Hypothesis Testing 2

\begin{tabular}{|l|l|l|l|l|l|l|l|}
\hline \multicolumn{2}{|c|}{ Variables in the Equation } \\
\hline \multicolumn{2}{|c|}{} & \multicolumn{1}{|c|}{ B } & \multicolumn{1}{c|}{ S.E. } & \multicolumn{1}{c|}{ Wald } & df & Sig. & Exp(B) \\
\hline \multirow{3}{*}{$\begin{array}{l}\text { Step } \\
1\end{array}$} & PROCYCLICAL & 3.845 & .535 & 51.736 & 1 & .000 & 46.781 \\
\cline { 2 - 8 } & LEV & 4.433 & 6.865 & .417 & 1 & .518 & 84.167 \\
\cline { 2 - 9 } & MODERASI & .647 & .268 & 5.820 & 1 & .016 & 1.910 \\
\cline { 2 - 9 } & Constant & -5.855 & 5.944 & .970 & 1 & .325 & .003 \\
\hline
\end{tabular}

The test table above is done to be able to determine the level of influence of procyclical variables and financial leverage on income smoothing. logistic regression test results above obtained regression coefficient value of 0.647 with a significance value of 0.016 . The value of the significance level explains the value smaller than $0.05(\mathrm{p} \leq 0.05)$. This can explain the second hypothesis is accepted, so that procyclical variables with financial leverage moderating variables can affect income smoothing.

The results of research conducted by researchers shows that procyclical and financial leverage affect the occurrence of income smoothing actions in banking companies. The leverage ratio will be shown on the value of the company's assets that have been funded by the debt financing. When the leverage ratio is quite high, it can cause a decrease in the interest of investors in investing in the company, especially in banking companies. Therefore, when there is a decrease in investor interest due to the high leverage ratio, it can trigger income smoothing. The existence of research that is above that procyclical and financial leverage as moderation has a considerable influence in the act of cheating income smoothing in line with research conducted by Alexandri and Anjani (2014) which according to data that has been taken related to financial leverage shows the results of positive for the occurrence of the income smoothing action.

\section{CONCLUSiOnS, Limitations, AND SUgGESTIONS}

In this study the aim is to examine the effect of procyclical on income smoothing with financial leverage as a moderating variable. The results of research and analysis carried out on conventional banking companies listed on the Indonesia Stock Exchange in the observation period of 2012-2016 with a total of 29 companies that have met the research criteria. Test results and analysis show that procyclical has a positive effect on income smoothing. With the existence of a procyclical pattern in achieving a goal, it has a considerable influence on information asymmetry (income smoothing), so that when some companies experience financial difficulties or are in crisis conditions, the actions of a manager will commit fraud to be able to give more confidence to investors to persist in investing. This shows that banks that have a high risk value in carrying out their financing activities will tend to perform procyclical patterns for income smoothing purposes. 
The results of the testing and analysis show that financial leverage can moderate the significant positive effect of procyclical on income smoothing. This shows that when a company experiences a financial crisis, managers do form information asymmetry by forming a procyclical pattern of action. It is also strongly influenced by considerable financial leverage in deviating the income smoothing in order to increase investor interest in investing and making company profits increase, so that the company's risk will be smaller. Based on the results of research that has been obtained in the study, there are some limitations in this study. Sample data on banking companies presented by the Indonesia Stock Exchange lacks the same completeness. There are a number of sample banks issuing financial reports for only 3 (three) years, and for samples of other banks can use their financial statements for 5-10 years of observation. In addition, the sample of companies used in this study was too small, because only a few banking companies in Indonesia that went public. As well as sample companies only use one country only, so that they cannot distinguish banks in one country from another.

Therefore based on the limitations that already exist in the study, then there are suggestions that can be given for further research, namely the limited sample data presented in the Indonesia Stock Exchange, then further research is recommended to use secondary data on the company's financial statements through the Bankscope database. or through the respective banking sites that have been published. By using the published financial report data, it can analyze it more comprehensively. Besides that, there is also a limited number of samples used in this study, so it is hoped that further research will add banking companies that are only unconventional but can also use Islamic banking companies that already exist in Indonesia. Or it can also add banking companies that exist in crosscountry, for example comparing with banking companies in Asia and so on in order to see the results of comparison in conducting research related to the influence of procyclical on income smoothing that uses financial leverage moderation.

\section{REFERENCES}

[1] Alexandri, M. B., \& Anjani, W. K. (2014). Income smoothing: impact factors, evidence in Indonesia. Abstrak.

[2] Annisya, M., \& Asmaranti, Y. (2016). Pendeteksian Kecurang Laporan Keuangan Menggunakan Fraud Diamond. Jurnal Bisnis dan Ekonomi, 23(1).

[3] Ashari, d. (1994). Factor Affecting Income Smoothing Among Listed Companies in Singapore. Journal of Accounting and Bussiness Reserch, Auntum 291-304.

[4] Astika, M. U. T. d. I. B. P. (2017). Pengaruh Profitabilitas Dan Financial Leverage Pada Income Smoothing Dengan Ukuran Perusahaan Sebagai Variabel Pemoderasi. E-Jurnal Akuntansi Universitas Udayana, 20, 2273-2302.

[5] Beidleman, C. R. (1973). Income smoothing: The role of management. The Accounting Review, 48(4), 653-667.

[6] Borio, C. E., English, W. B., \& Filardo, A. J. (2003). A tale of two perspectives: old or new challenges for monetary policy?

[7] Breton, G., \& Stolowy, H. (2000). A framework for the classification of accounts manipulations.

[8] Carvallo, O., Kasman, A., \& Kontbay-Busun, S. (2015). The Latin American bank capital buffers and business cycle: Are they pro-cyclical? Journal of International Financial Markets, Institutions and Money, $36,148-160$.

Citation: Aprilya Dwi Yandar, Erina Sudaryati. "The Effect of Procyclical on Income Smoothing with Financial Leverage as Moderation Variables in Banking Companies". International Journal of Managerial Studies and Research (IJMSR), vol 6, no. 11, 2018, pp. 64-68. doi: http://dx.doi.org/10.20431/ 23490349.0611007.

Copyright: (C) 2018 Authors. This is an open-access article distributed under the terms of the Creative Commons Attribution License, which permits unrestricted use, distribution, and reproduction in any medium, provided the original author and source are credited. 